\title{
Vascular epiphytes in urban trees in Goiânia city, Brazilian Cerrado ${ }^{1}$
}

\author{
Talita Nunes de Castro Figueiredo ${ }^{2}$; Jorge Luís Sousa Ferreira ${ }^{3}$; Francine Neves Calil ${ }^{4}$; Jácomo Divino \\ Borges $^{5}$; Carlos de Melo e Silva Neto ${ }^{6}$
}

\begin{abstract}
The objective of this study was to evaluate the presence of epiphyte species in trees that compose the urban trees of four avenues of Goiânia city - state of Goiás. All individuals from the avenue median and sidewalks were quantified, all epiphyte host individuals were inventoried and the epiphytes found were evaluated qualitatively and quantitatively. The species Ficus rubiginosa was present in $68.63 \%$ of the cases, followed by Ficus luschnathiana (15.69\%), Ficus insipida (5.88\%) and Ficus guaranitica (5.88\%). A total of $84.62 \%$ of the hosts are Poincianella pluviosa, 51.92\% are individuals of height between 14 and 16 meters and $35.29 \%$ have a diameter between 46.00 and $61.99 \mathrm{~cm}$. The hemiepiphytes occurred on Libidibia ferrea, Ceiba speciosa, Albizia lebbeck and Pachira aquatica. The occurrence of hemiepiphytes prevailed on trunk bifurcations (44.23\%), branch bifurcation (19.23\%), branch hollows (17.31\%) and on branches and roots $(3.85 \%)$. About $15.65 \%$ of each adult arboreal in Goiânia city is inferred to hold at least one epiphyte.
\end{abstract}

Keywords: Arboriculture; Urban silviculture; Urban afforestation; Hemiepiphyte; Primary hemiepiphyte.

\section{Epífitas vasculares em árvores urbanas na cidade de Goiânia, Cerrado brasileiro}

Resumo: O objetivo deste estudo foi avaliar a presença de espécies epífitas em árvores que compõem as árvores urbanas de quatro avenidas da cidade de Goiânia - GO. Todos os indivíduos da avenida mediana e calçadas foram quantificados, todos os indivíduos hospedeiros das epífitas foram inventariados e as epífitas encontradas foram avaliadas qualitativa e quantitativamente. A espécie Ficus rubiginosa esteve presente em 68,63\% dos casos, seguida por Ficus luschnathiana (15,69\%), Ficus insipida (5,88\%) e Ficus guaranitica (5,88\%). Um total de 84,62\% dos hospedeiros são Poincianella pluviosa, 51,92\% são indivíduos de altura entre 14 e 16 metros e 35,29\% têm diâmetro entre 46,00 e 61,99 cm. Os hemiepífitos ocorreram em Libidibia ferrea, Ceiba speciosa, Albizia lebbeck e Pachira aquatica. A ocorrência de hemiepífitos prevaleceu nas bifurcações de tronco (44,23\%), bifurcação de galhos $(19,23 \%)$, cavidades de galhos $(17,31 \%)$ e nos galhos e raízes $(3,85 \%)$. Cerca de $15,65 \%$ de cada adulto arbóreo em Goiânia é inferido como portador de pelo menos uma epífita.

Palavras - chave: Arboricultura; Silvicultura urbana; Arborização urbana; Hemiepífito; Hemiepífito primário

\footnotetext{
${ }^{1}$ Received on 20 March 2021 and accepted for scientific article publication on 05 May 2021.

${ }^{2}$ Forest Engineer. Federal University of Goias, Goiás city, GO, Brazil. E-mail: < talitanunesdecastro@ hotmail.com>

${ }^{3}$ Agronomic Engineer, Dr. Federal University of Goias, Goiás city, GO, Brazil. E-mail: <jorgeluisferreira89@ hotmail.com>

${ }^{4}$ Forest Engineer, Dra. Professor at Federal University of Goias, Goiás city, GO, Brazil. E-mail: <fncalil@ gmail.com>

${ }^{5}$ Biologist, Dr. Professor at Federal University of Goias, Goiás city, GO, Brazil. E-mail: 〈jacomo.borges@ gmail.com>

${ }^{6}$ Biologist, Dr. Researcher at Federal Institute of Goiás, Goiás, GO city, Brazil. E-mail: <carloskoa@ gmail.com>
} 


\section{Introduction}

The stranglers stand out among the primary woody hemiepiphytes, which develop until reaching large sizes after contacting water and soil nutrients stocks, being able to self-support (COELHO, 2005). The strangler hemiepiphytes pass through the epiphytic, hemiphytic and arboreal (or free-living) phases during their development, competing with hosts for water, soil, nutrients and opportunities to reach the canopy. The constriction caused to the stem and branches of the host by the system of strangulating roots (typical of these stranglers), hampers the translocation of water and nutrients through its vascular system, which can lead to the premature death of the host.

The best-known representatives of this group of epiphytes are the fig trees (Jamaican cherry fig or West Indian laurel fig; genus Ficus, family Moraceae), which attach their roots to the stem of the host. Its roots propagate vegetatively from the budding of the main root, the initial stem region and the ventral portion of the low branches (COELHO, 2005; LUDWIG et al., 2019). The most common type of dispersion among individuals of the Ficus genus is ornithocoria (dispersal by birds). This genus does not perform asexual dispersion, being completely dependent on seed dispersal (DISLICH, 1996).

The species Ficus enormis, for example, has irregular distribution, which can be explained by the fact that, with no adult individuals in the area, there is no seed production and consequently no dispersal (Dislich, 1996). In other words, epiphytic, immature individuals are not able to produce fruits and seeds. The fruit produced by most ornithocoric epiphytic species are dehiscent and fleshy, and have larger and fewer seeds than the observed for Orchidaceans, however having larger and more seeds than related terrestrial species (KERSTEN, 2006; QUARESMA and JARDIM, 2014).

The epiphyte distribution seems to be closely linked to water and photic relationships within a forest plant community such as tropical forests; the to the canopy, the lower the humidity and the greater the luminosity. This microclimatic gradient from the soil surface to the tree canopy affects epiphyte species distribution along the support plant (MANIA, 2008; MARCUSSO et al., 2019).

Some epiphytic species are associated with a particular forophytic species, which can lead to a successful epiphyte colonization (BUZATTO et al. 2008). The relevant factors as regards the host plant are architecture and size of the trees, texture and porosity of the bark for retention and storage of water, etc. (BORGO and SILVA, 2003), each species having a specific architectural model (SEITZ, 1996; COBLE et al., 2017). Size, shape of the canopy, arrangement of leaves and flowers, are structural characteristics common to individuals of the same species, receiving the title of architectural model of the species. Therefore, the distribution of the epiphytic species can vary vertically, and horizontally (i.e., from the base to the top of the host) occupying the low and high stems, and the canopy, and between the supporting tree species (MANIA, 2008).

According with the Master Plan of Afforestation of Goiânia (2008), the afforestation of Goiânia city began between the 40's and 50's, when the first districts of the city were founded. Exotic species prevailed, including Delonix regia (Bojer ex Hook.) Raf., Pachira aquatica Aubl., Ficus sp. (Ficus), trees that prevail in the oldest neighborhoods. The species Poincianella pluviosa var. peltophoroides (Benth.) L. P. Queiroz and Cassia javanica L. began to be used in the city in 50's. As the urban trees extended to the other sectors of Goiânia, the same species continued being used.

Epiphytes are poorly studied in urban environments. More recent research has surveyed epiphytes within the municipalities of Luiziana (DEVENS et al. 2015) and Farol, both in state of Paraná (Brazil) (RITTER et al. 2014), and have studied the vascular epiphytic component in urban trees of a square in downtown in Piratininga city, state of São Paulo (FABRICANTE et al. 2006). No research 
on hemiepiphytes in urban trees, strangler hemiepiphytes in urban areas or either for the state of Goiás have been found. This study is justified, therefore, by the scarcity of studies regarding primary hemiepiphytes in urban trees, since its existence can impair the maintenance of the urban trees, due to its strangulating behavior. Given the lack of studies on epiphytes in Goiânia, this study aims to evaluate the presence and behavior of epiphyte species in tree individuals that compose the urban trees in an avenue in the city of Goiânia, state of Goiás, Brazil.

\section{Material and methods}

The city of Goiânia, capital of Goiás state, located in the central region of Brazil, has a population of $1,448,639$ people in an area of $728,841 \mathrm{~km}^{2}$ (IBGE, 2016). The climate of Goiânia, is Aw (tropical with dry winter), according to the Köppen-Geiger classification, with average annual temperature of $23.4{ }^{\circ} \mathrm{C}$ and average annual precipitation around $1,500 \mathrm{~mm}$ (CARDOSO et al. 2014). Goiânia is located within a region typical of the Cerrado biome, for which the gallery forests have characteristics that favor the occurrence of epiphytes (OLIVEIRA, 2013).

The study was carried out with individuals that constitute urban trees of São Francisco Avenue (SF Avenue), beginning when it crosses the Gaipá Street (Latitude: 16³8'0.17" S Longitude: $49^{\circ} 14^{\prime} 11.30^{\prime \prime} \mathrm{W}$ ) in the northwest direction. The evaluations followed Avenues Meia Ponte, Vereador José Monteiro and Quinta, ceasing evaluations upon crossing Independência Avenue (Latitude: 16³9'35.75"S Longitude: 49¹4'49.17" W).

All individuals from the avenue medians, and from the right and left sidewalks were quantified and categorized into stumps, regrowth, shrubs, seedlings (up to $2 \mathrm{~m}$ ), young ( 2 to $6 \mathrm{~m}$ ) and adults' trees (more than $6 \mathrm{~m}$ ). Where SF Avenue meets Caiapó Avenue, only the avenue median closest to SF Avenue was quantified. All individuals found with epiphytes and, or, other plants developing in some part of their structure, were subsequently identified and evaluated.

The evaluations were carried out from August to November 2016. Information was collected following Coelho (2005), with adaptations to the local reality. Thus, the following information was obtained from each individual with epiphyte: geographical coordinate, species of hosts tree were identified, height $(\mathrm{m})$, diameter at breast height $(\mathrm{DBH})$ (cm); size (stumps, regrowth, shrubs, seedlings, young and adult); amount of epiphytes; condition of the epiphyte (true epiphytic behavior; with apparent emission of adventitious roots; roots clasping the host; and dead); insertion of the epiphyte (s) (trunk bifurcation; forked branches; branch; branch hollow; root hollow and undefined); and photographic record of the epiphyte (s).

Epiphytes were recorded as with "roots clasping the host" when the adventitious roots had embraced the host. Some epiphytes were recorded as dead when there were no leaves, as a consequence of a total pruning of its crown, leaving stumps or stumps and roots. The "insertion of the epiphyte" was "undefined" when the epiphyte was occupying an area above the host which prevented us from determining where the epiphyte was inserted for germination. It is truly possible for the insertion site to be undefined (COELHO, 2005) due to the way its roots propagate.

An electronic Clinometer (Haglöf Sweden) was used to measure the height of the species with the epiphyte. A GPS receiver (Garmin eTrex 20) was used to obtain the geographical coordinates of each tree. The data were evaluated with descriptive statistics and a correlation was made between the results, namely Absolute and Relative Frequencies, according to the following equation 1 (Eq. 1):

$R F_{i}=\frac{F_{i}}{n} * 100$

where:

$\mathrm{RF}_{\mathrm{i}}$ : relative frequency of the $i^{\text {th }}$ element (\%);

Fi: absolute frequency of the element;

$\mathrm{n}$ : total number of items evaluated. 
The height and DBH of the epiphyte hosts were also analyzed graphically, using histograms of size classes, following Coelho (2005). To compare the structural parameters of the trees that presented epiphytes, we performed a correlation between tree species height of insertion of the epiphyte, height of the tree, height of the branch of the tree and diameter at breast height $(\mathrm{DBH})$. Statistical significance was verified with $95 \%$ significance and the correlation coefficient was observed for significant pairs

\section{Results}

A total of 230 individuals of 17 species were quantified in approximately 10 families (Anacardiaceae, Arecaceae, Bignoniaceae, Chrysobalanaceae, Combretaceae, Malvaceae, Myrtaceae, Moraceae, Rutaceae, and Sapindaceae), among stumps, regrowth, shrubs and tree elements. Only six species, belonging to the least abundant species group, were not identified. The Fabaceae family was the most abundant. The list of species is shown in Table 1 .

Table 1 - Species found in the urban trees of Avenues São Francisco, Vereador José Monteiro, Meia Ponte and Quinta Avenue, in Goiânia city, state of Goiás, Brazil

Tabela 1 - Espécies encontradas nas árvores urbanas das Avenidas São Francisco, Vereador José Monteiro, Meia Ponte e Quinta Avenida, em Goiânia, Goiás, Brasil

\begin{tabular}{|c|c|c|c|}
\hline Species & Family & $\begin{array}{c}\text { Relative } \\
\text { Frequency }\end{array}$ & $\begin{array}{c}\text { Presence of } \\
\text { epiphyte }\end{array}$ \\
\hline Poincianella pluviosa var. peltophoroides (Benth.) G. P. Lewis & Fabaceae & $32.59 \%$ & yes \\
\hline Libidibia ferrea var. leiostachya (Benth.) L. P. Queiroz & Fabaceae & $18.50 \%$ & yes \\
\hline Ceiba speciosa (A. St.-Hil.) Ravenna & Malvaceae & $14.09 \%$ & yes \\
\hline Albizia lebbeck (L.) Benth. & Fabaceae & $10.50 \%$ & yes \\
\hline Pachira aquatica Aubl. & Malvaceae & $10.50 \%$ & yes \\
\hline Licania tomentosa (Benth.) Fritsch & Chrysobalanaceae & $7.46 \%$ & no \\
\hline Mangifera indica $\mathrm{L}$. & Anacardiaceae & $4.40 \%$ & no \\
\hline Handroanthus spp. & Bignoniaceae & $3.28 \%$ & no \\
\hline Roystonea oleracea (Jacq.) O. F. Cook & Arecaceae & $1.30 \%$ & no \\
\hline Sapindus saponaria $\mathrm{L}$ & Sapindaceae & $1.30 \%$ & no \\
\hline Delonix regia (Bojer ex Hook.) Raf. & Fabaceae & $0.40 \%$ & no \\
\hline Caesalpinia pulcherrima (L.) Sw. & Fabaceae & $0.40 \%$ & no \\
\hline Apuleia leiocarpa (Vogel) J. F. Macbr. & Fabaceae & $0.40 \%$ & no \\
\hline Artocarpus heterophyllus Lam. & Moraceae & $0.40 \%$ & no \\
\hline Schizolobium parahyba (Vell.) S. F. Blake & Fabaceae & $0.40 \%$ & no \\
\hline Leucaena leucocephala (Lam.) de Wit & Fabaceae & $0.40 \%$ & no \\
\hline Bauhinia forficata Link & Fabaceae & $0.40 \%$ & no \\
\hline
\end{tabular}

A total of $68.66 \%$ of the individuals were adults, $20.30 \%$ were juveniles, $4.48 \%$ were seedlings, $2.98 \%$ were shrubs, $2.09 \%$ were stumps and $1.49 \%$ were regrowth. The most abundant species (over 10 individuals) were of tree individuals. Most individuals are arboreal of the species Poincianella pluviosa var. peltophoroides (Benth.) G. P. Lewis (32.59\% of the individuals), followed by Libidibia ferrea var. leiostachya (Benth.) L. P. Queiroz (brazilian ironwood; 18.5\%), Ceiba speciosa
(A. St.-Hil.) Ravenna (silk floss tree; 14.09\%), Pachira aquatica Aubl. (10.5\%), Albizia lebbeck (L.) Benth. (10.5\%), Licania tomentosa (Benth.) Fritsch (7.46\%), Mangifera indica L. (4.4\%) and Handroanthus spp. (3.28\%). The remaining individuals with less than 10 representatives per species are included in the remaining $17.62 \%$.

Epiphytes only occurred in adult trees. A total of 230 adult trees were evaluated, and the species found with epiphytes were $P$. pluviosa 
(32.61\%), L. ferrea (18.26\%), C. speciosa (13.91\%), A. lebbeck (10.43\%) and P. aquatica (10.43\%). The other $14.36 \%$ comprised other species that did not hold epiphytes.

Epiphytes were found in proportionally larger numbers in the most abundant species of adult individuals, in 36 trees. The species $P$. pluviosa exhibited the highest number of epiphytes (host for $84.62 \%$ of the epiphytes), followed by $L$. ferrea (host in $7.69 \%$ ), $C$. speciosa (3.85\%), A. lebbeck and P. aquatica, (both with only $1.92 \%$ of the epiphytes). Most epiphytes $(35.29 \%)$ belong to the $14-16$-meter class (Figure 1), whereas the average height of the hosts was 13.57 meters.

Some individuals were host to more than one epiphyte. Individuals with a diameter at breast height (DBH) ranging from $14.96 \mathrm{~cm}$ to 108.23 $\mathrm{cm}$ were recorded, in addition to a single host with a DBH of $175.71 \mathrm{~cm}$. This individual with higher DBH was considered an outlier and removed from the diameter class histogram to facilitate the visualization of the results. Therefore, most of the epiphytes held individuals in the diameter classes of $46-62 \mathrm{~cm}$ (35.29\% of the epiphytes), as shown in Figure 2.

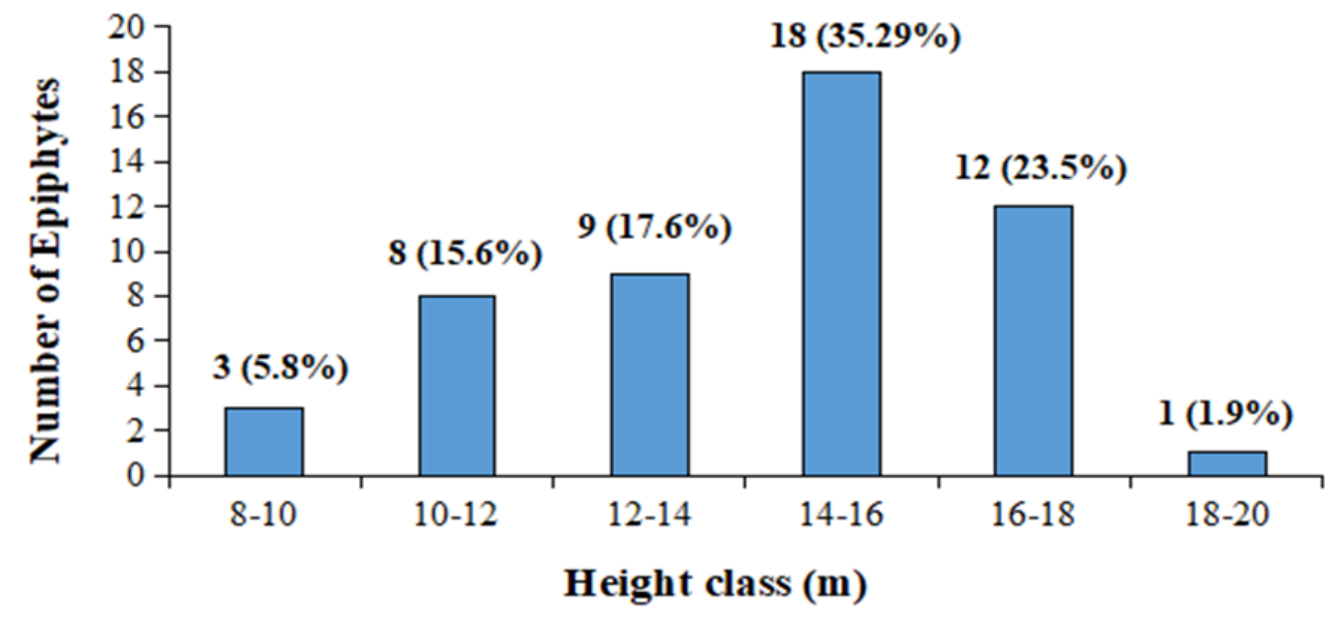

Figure 1 - Number of epiphytes per height of host trees distribution ranked into classes.

Figura 1 - Número de epífitas por altura na distribuição de árvores hospedeiras classificadas em classes.

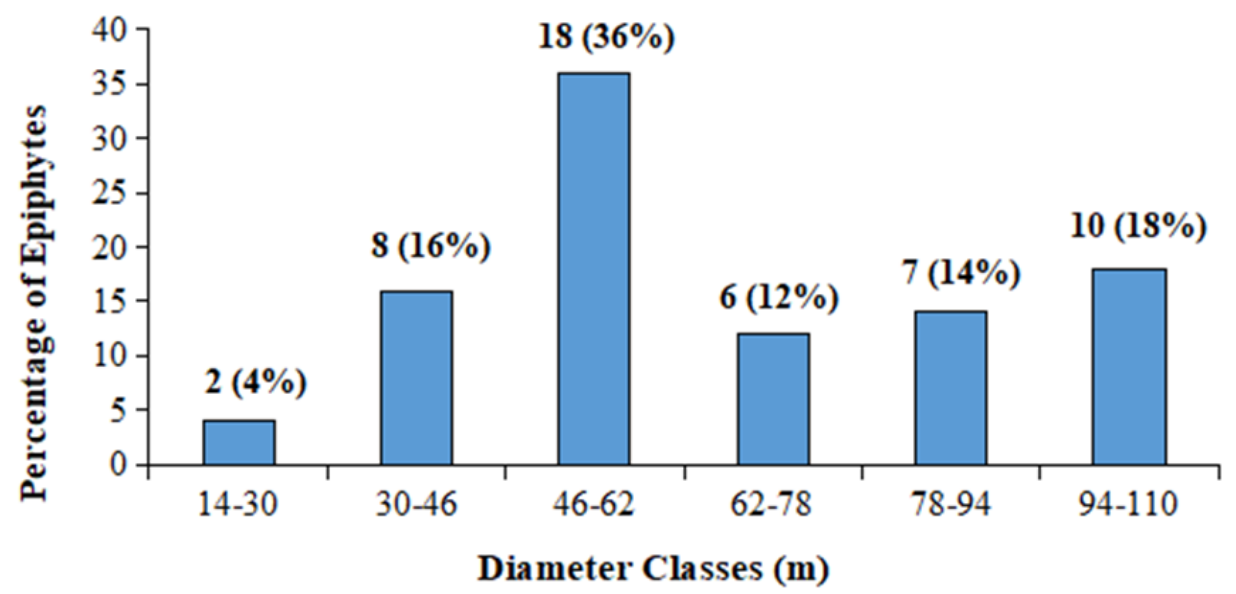

Figure 2 - Percentage of epiphytes that occurred in the different host tree diameter classes.

Figura 2 - Porcentagem de epífitas que ocorreram nas diferentes classes de diâmetro da árvore hospedeira. 
A tree and a shrub species were observed developing on adult trees. This occurrence was observed on a specimen of $P$. pluviosa var. peltophoroides as an individual of Tecoma stans (L.) Juss. ex Kunth (seedling phase) was developing in the hollow of its roots. An Anadenanthera sp. seedling was also observed in the bifurcation of a trunk of an individual of A. lebbeck.

A total of 51 epiphytes were recorded, and all were primary hemiepiphytes of the genus Ficus, family Moraceae, commonly known as stranglers. No other type of epiphyte was identified. Most host plants $(75 \%)$ had only one epiphyte. Some of these support plants could host from one to five epiphytes. On average $25 \%$ of hosts had more than one hemiepiphytes, being $13.89 \%$ with two hemiepiphytes, $5.56 \%$ with three, $2.78 \%$ with four and five hemiepiphytes.

Four Ficus species were recorded in this study, Ficus cf. rubiginosa Desf. ex Vent (sp1), Ficus luschnathiana (Miq.) Miq. (sp2), Ficus insipida Willd. (sp3) and Ficus guaranitica Chodat (sp4) (Figure 3). The species F. rubiginosa was present in $68.63 \%$ of the cases, followed by $F$. luschnathiana (15.69\%), $F$. insipida (5.88\%) and F. guaranitica (5.88\%), (the other ones where undefined because they were dead, $3.92 \%$ ).

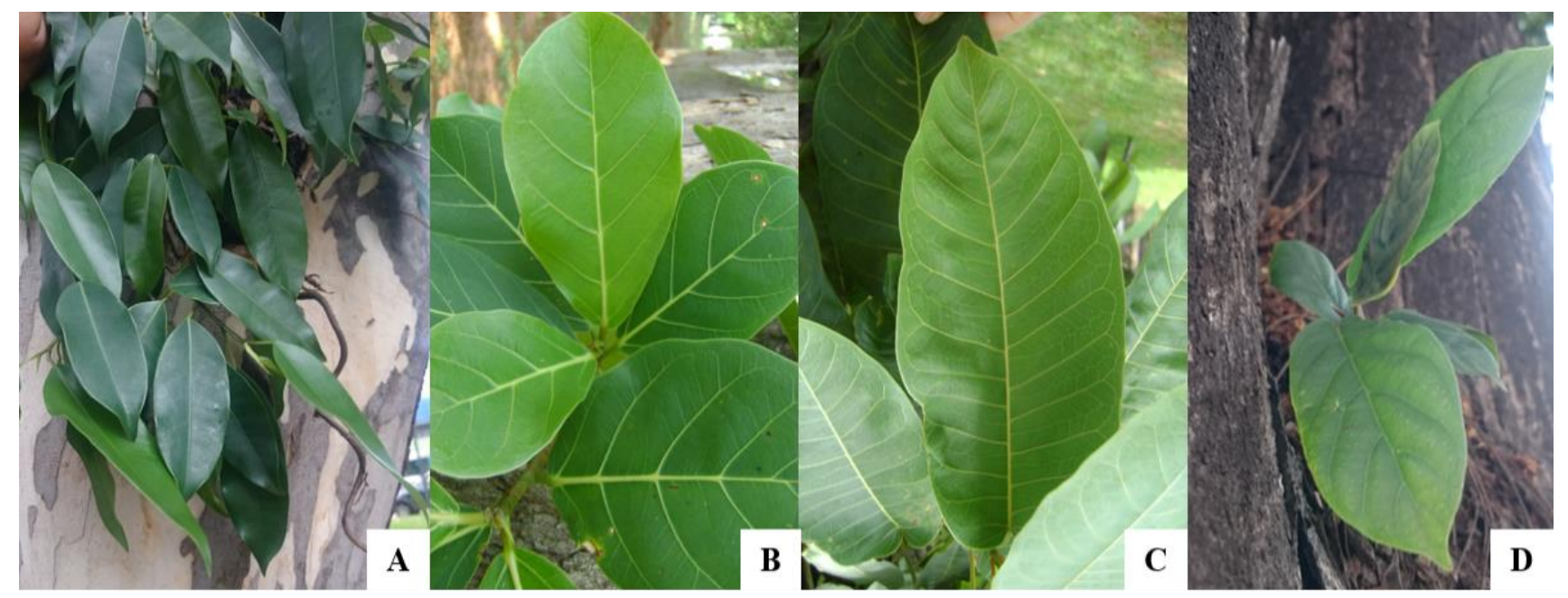

Figure 3 - Species found. A. Ficus cf. rubiginosa Desf. ex Vent.; B. Ficus luschnathiana (Miq.) Miq.; C. Ficus insipida Willd; e D. Ficus guaranitica Chodat

Figura 3 - Espécies encontradas. A. Ficus cf. rubiginosa Desf. ex Vent.; B. Ficus luschnathiana (Miq.) Miq.; C. Ficus insipida Willd.; e D. Ficus guaranitica Chodat

Most hemiepiphytes were already found with adventitious roots $(51.92 \%)$. It is noteworthy that $23.08 \%$ of the hemiepiphytes still had true epiphytic behavior. It was identified that $21.15 \%$ of the epiphytes had reached a stage where the host could be being negatively affected, by the constriction of trunk or branches through its roots. Hemiepiphytes can cause different levels of damage to their hosts, as observed in Figure 4.
A total of $44.23 \%$ of the 51 hemiepiphyte individuals recorded were located on trunk bifurcation and $19.23 \%$ on ranch bifurcation, resulting in $63.46 \%$ individuals located in bifurcations. A total of $17.31 \%$ of the hemiepiphytes were found in hollow of branches, being only $3.85 \%$ in branches, and $3.85 \%$ in the hollow of the roots. It was not possible to show the insertion location of part of the hemiepiphytes (9.62\%) (Figure 5). Only 
a correlation was found between the insertion of the epiphyte and the height of the bifurcation $(\mathrm{R}$ $=0.32261 ; \mathrm{p}=0.04$; Table 2), as expected, since the epiphyte mostly depends on the bifurcation for support. Other structural aspects (height of the tree, height of the branch of the tree and diameter at breast height $\mathrm{DBH}$ ) or species were not related.

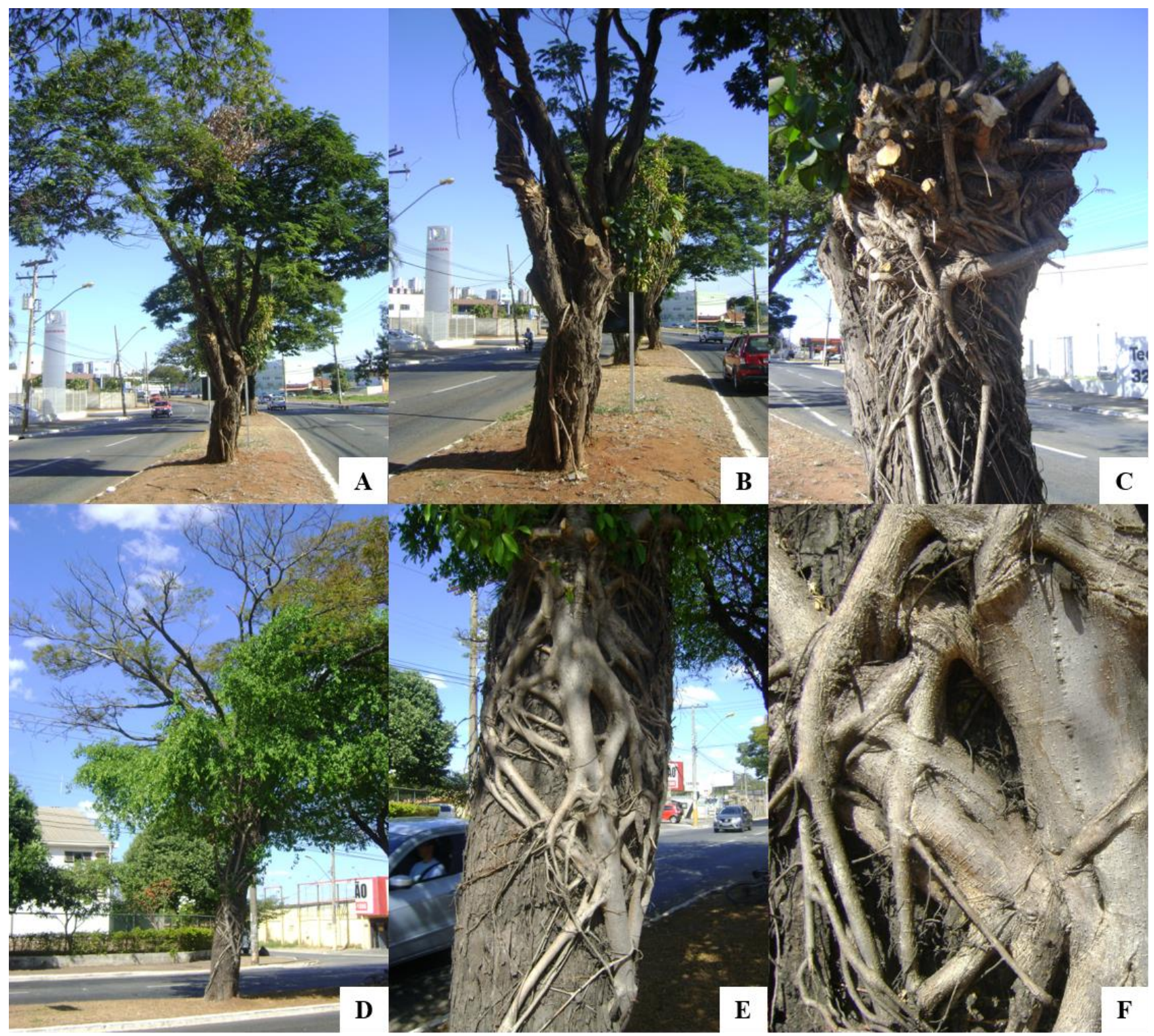

Figure 4 - Examples of the host species Poincianella pluviosa var. peltophoroides found carrying strangulating hemiepiphytes causing damage through their roots - A. First specimen, whole individual; B. First specimen, highlighted; C. First specimen showing the damage caused by the epiphyte and its strangulating roots; D. Second specimen, whole individual; E. Second specimen, highlighted, showing root fixation; F. Second specimen, showing the strangulating roots.

Figura 4 - Exemplos da espécie hospedeira Poincianella pluviosa var. peltophoroides encontrados carregando hemiepífitas estrangulantes causando danos através de suas raízes - A. Primeiro espécime, indivíduo inteiro; B. Primeiro espécime, destacado; C. Primeiro espécime mostrando o dano causado pela epífita e suas raízes estrangulantes; D. Segundo espécime, indivíduo inteiro; E. Segundo espécime, destacado, mostrando a fixação da raiz; F. Segundo espécime, mostrando as raízes estrangulantes. 


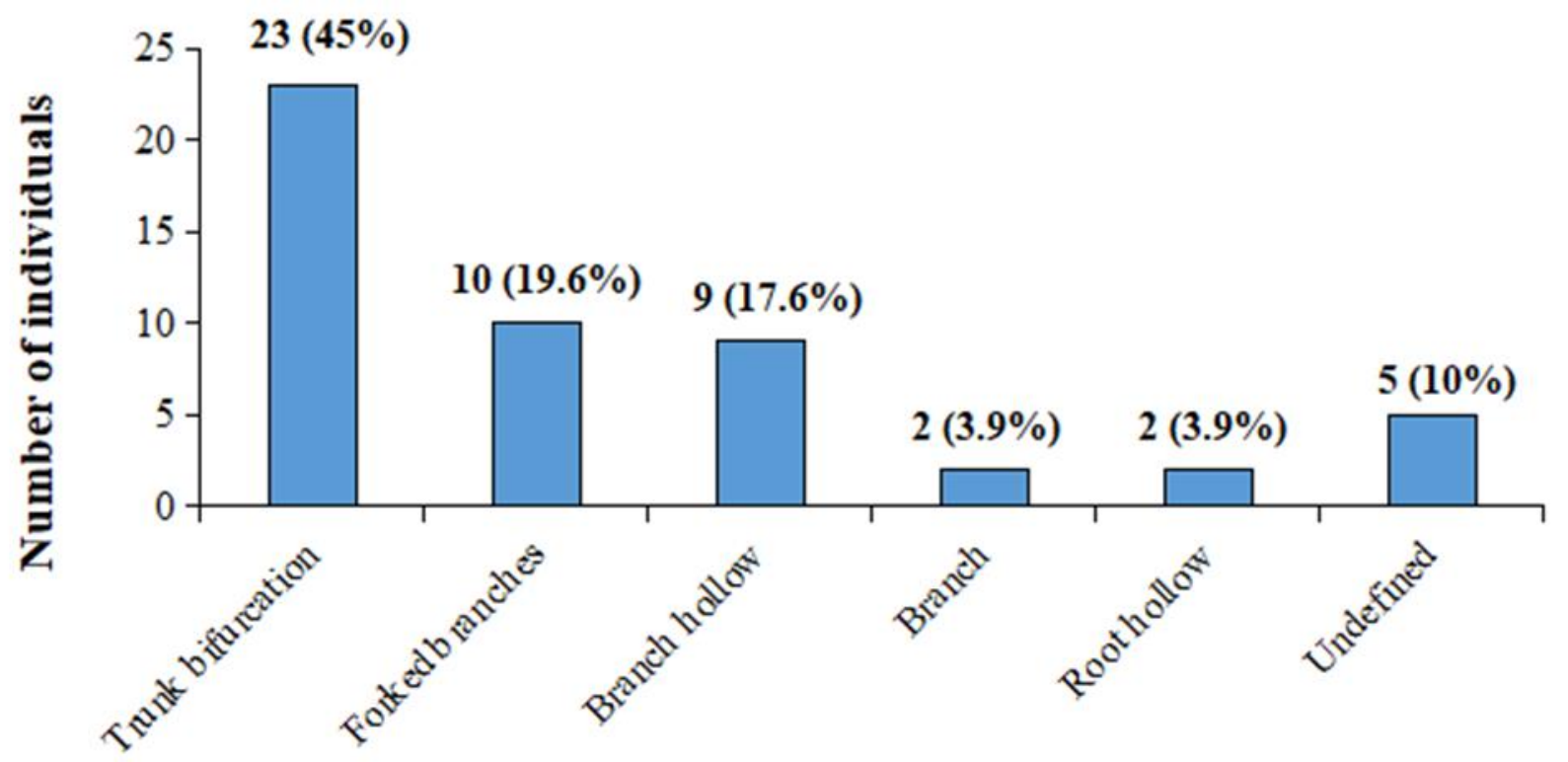

Figure 5 - Location of the hemiepiphytes in the host trees.

Figura 5 - Localização dos hemiepífitos nas árvores hospedeiras.

Table 2 - Correlation between tree species height of insertion of the epiphyte, height of the tree, height of the branch of the tree and diameter at breast height (DBH).

Tabela 2 - Correlação entre as espécies de árvores, altura de inserção da epífita, altura da árvore, altura do galho da árvore e diâmetro à altura do peito (DAP).

\begin{tabular}{cccccc}
\hline & Tree species & Insertion of epiphyte & Tree height & Height of tree branch & DBH \\
\hline Tree species & 0 & 0.92397 & 0.58078 & 0.30546 & 0.741 \\
Insertion of epiphyte & - & 0 & 0.096402 & $\mathbf{0 . 0 4 8 2 1 9}$ & 0.73993 \\
Tree height & - & - & 0 & 0.36903 & 0.70193 \\
Height of tree branch & - & $\mathbf{0 . 3 2 2 6 1}$ & - & 0 & - \\
DBH & - & - & - & - & 0
\end{tabular}

*Table form: Correlation/ $\mathrm{p}$ value; $\mathrm{DBH}=$ Diameter at breast height

\section{Discussion}

Most of the tree species found in the region evaluated were species used at the beginning of urban trees of Goiânia (early 40's). The Master Plan of Afforestation of Goiânia (PDAU, 2008), reports that $19.15 \%$ of the trees in Goiânia are $P$. aquatica, $17.05 \%$ are $P$. pluviosa var. peltophoroides (the most frequent tree species in this study), $0.89 \%$ are C. speciosa,
$0.87 \%$ are A. lebbeck and $0.36 \%$ are Libidibia ferrea var. leiostachya. The afforementioned species are the most abundant species of this study. These species were also found carrying primary hemiepiphytes, only in adult individuals. In contrast, Weirich et al. (2015) recorded the species Roystonea oleracea (Jacq.) O.F. Cook as the most frequent, common at Av. Goiás and Av. Planície, followed by $P$. aquatica, Handroanthus spp. and L. tomentosa. 
Specimens of $P$. aquatica, Handroanthus spp. and L. tomentosa are among the species with over 10 specimens in the avenues evaluated in this study. Still the most frequent species were P. pluviosa var. peltophoroides and Libidibia ferrea var. leiostachya.

The species $P$. pluviosa is found more frequently in the region evaluated by the current study than proportionally for all of Goiânia. This species was also the most commonly found carrying hemiepiphytes, and the only species carrying more than three epiphytes and more than one species of hemiepiphyte per host. It can be inferred that $15.65 \%$ of the adult trees of the city of Goiânia will present at least one epiphyte. Oliveira (2013) studied Gallery forests of the Cerrado biome in Distrito Federal, in two environments (flooded and non-flooded), and found that $31.6 \%$ of the tree individuals had epiphytes.

In this study, only five species were recorded as hosts, and only of primary hemiepiphyte species. A total of $84.62 \%$ of the epiphytes were recorded on specimens of $P$. pluviosa and the remainder on L. ferrea, C. speciosa, A. lebbeck and $P$. aquatica (on a descending order). Devens et al. (2015), found three common tree species in the urban trees of Luiziana (state of Paraná, Brazil; Mixed Ombrophilous Forest Domain), namely: Ligustrum lucidum W.T. Aiton., P. pluviosa var. peltophoroides and Schinus molle L.. Most of the trees evaluated were L. lucidum (44.28\%) holding $67.4 \%$ of the epiphytes, followed by $P$. pluviosa $(33.17 \%)$ with $58.9 \%$ of the epiphytes. A total of $22.54 \%$ of the individuals were $S$. molle, with one specimen of Dendrobium nobile Lindl (a cultivated orchid). Ritter et al. (2014) studied an ecotone between a Seasonal Semideciduous Forest and Mixed Ombrophylous Forest (municipality of Farol, state of Paraná, Brazil), and reported that $90 \%$ of the epiphytes from Farol can be found using L. lucidum as a phorophyte.

Devens et al. (2015), found 11 epiphyte species in trees from Paraná, comprising five families, where $72.70 \%$ were of the Bromeliaceae and Polypodiaceae families. The only primary hemiepiphyte found (Philodendron bipinnatifidum Schott ex Endl.) belonged to the genus Araceae and had zoocoric dispersion, corresponding to $9.09 \%$ of the epiphytes. Ritter et al. (2014), (similar to Devens et al., 2015), recorded seven epiphytic families (Polypodiaceae and Bromeliaceae prevailed) and ten predominantly true epiphyte species, with no hemiepiphytes in state of Paraná. These results contrast with this study, since only primary hemiepiphytes of the family Moraceae, genus Ficus, were recorded.

Only three species of primary hemiepiphytes were found in the Fontes do Ipiranga State Park, São Paulo city - state of São Paulo, Brazil, all belonging to the Family Araceae and with endozoic dispersion: Philodendron appendiculatum Nadruz \& Mayo Philodendron bipinnatifidum Schott ex Endl. and Philodendron loefgrenii Engl. The host trees were on average 10 and 12 meters high (SANTOS, 2008). The supporting trees, reported in this study, averaged $13.57 \mathrm{~m}$ in height. Only two species of primary hemiepiphytes (Anthurium intermedium Kunth and Philodendron crassinervium Lindl.; Araceae Family; endozoic dispersion) were recorded in the Restinga of the coastal plain of the Fazenda Praia do Serra do Mar State Park, municipality of Ubatuba - state of São Paulo, Brazil. A total of $52.7 \%$ of the hosts of the vascular epiphytes of the forest exhibited rhytidoma with a non-desolate rough texture (MANIA, 2008).

A total of eighteen Ficus tree species (family Moraceae) have been recorded in the Cerrado biome, namely: Ficus adhatodaefolia Schott. ex Spreng., Ficus calyptroceras (Miq.) Miq., Ficus citrifolia P. Miller, Ficus doliara Mart., Ficus enormis (Mart. ex Miq.) Miq., Ficus eximia Schott., Ficus gardneriana (Miq.) Miq. Ficus gomelleira Kunth. \& Bouché ex Kunth., Ficus guyanensis Desv. ex Ham., Ficus insipida Willd., Ficus luschnathiana Miq., Ficus maxima Miller, Ficus mexiae Standl., Ficus obtusifolia Roxb., Ficus obtisiuscula (Miq.) Miq., Ficus padifolia H. B. \& K., Ficus pertusa L. f. and, Ficus trigona L. f.. Interestingly, 
there are no true epiphytes in the trees of Goiânia, but only primary hemiepiphytes of the Moraceae family, which do not occur in the native Cerrado area. The native Cerrado area more suitable for epiphytes is the Gallery forests.

Some Ficus tree species were identified after inventorying the trees of Goiânia for the PDAU (2008), and $4.87 \%$ were Ficus benjamina L (also from the early afforestation of the city), $0.30 \%$ were Ficus lyrata Warb, $0.28 \%$ were Ficus microcarpa L. f., $0.03 \%$ were Ficus elastica Roxb., $0.023 \%$ were Ficus sp., $0.023 \%$ were Ficus insipida Willd., 0.008\% were Ficus guaranitica Chodat, $0.003 \%$ Ficus maxima Mill., and others. The epiphytes of the family Moraceae in Brazil are represented only by the genus Ficus (KERSTEN, 2006), the only genus recorded in this study.

Matos et al. (2010), recorded the species Ficus microcarpa L. f. (arboreal stage), a species considered an accidental epiphyte, in the urban trees of downtown Aracaju city- state of Sergipe, Brazil. Fabricante et al. (2006), evaluated the Square Professor José Inácio (municipality of Piratininga city- state of São Paulo, Brazil), and reported fifteen species as hosts of true and accidental epiphytes, and primary hemiepiphytes. Four species of the genus Ficus (Moraceae family) were recorded in this study, and corresponded to all of the epiphytes observed.

Fabricante et al. (2006), recorded two species of the Moraceae family: Ficus elastica Roxb. and Ficus macrocarpa H. Lév. \& Vaniot, $20 \%$ of the epiphytes of their study area. In addition, the authors recorded species of the Bromeliaceae (most abundant), Cactaceae, Orchidaceae, Polypodiaceae and Portulacaceae families. Kersten (2006), studied vascular epiphytes from the Upper Iguaçu river basin in eastern and southeastern of Paraná state, and recorded two species of the genus Ficus (Ficus luschnathiana (Miq.) Miq. and Ficus monckii Hassl.; $1.0 \%$ of the total sampled), reporting young individuals which were not strangling their host. We recorded $21.57 \%$ epiphytes of the genus Ficus with the roots surrounding the host, approaching strangulation. Contrasting with this study, Kersten (2006) reported that $45 \%$ of the species and $47 \%$ of the genera were of the Orchidaceae family.

Coelho (2005), evaluated only strangling hemiepiphytes in the Cardoso Island State Park (ICSP; Southernmost coast of São Paulo), and reported at least six species. Most of the species identified belonged to the subgenus Urostigma, in which hemiepifitism is frequent (Ficus enormis (Mart. Ex Miq.) Miq., Ficus gomelleira Kunth., Ficus organensis Miq. (Miq.), Ficus cf. glabra Vell. and Ficus arpazusa Casar). The author also identified individuals of Coussapoa microcarpa (Schott) Rizzini. The species in this study are possibly among previously reported Ficus species (PDAU, 2008; MATOS et al. 2010; FABRICANTE et al. 2006; KERSTEN, 2006; COELHO, 2005).

In this study, only five host were recorded with two fig trees, and Coelho (2005) recorded nine hosts with two fig trees. For him, most of the hosts sampled were over $16 \mathrm{~m}$ in height and $40 \mathrm{~cm}$ in diameter at breast height, therefore hemiepiphytes would occur mainly in the trees that make up the forest canopy and, to a lesser extent, in the understory trees. The hemiepiphytes recorded in this study were found mostly in hosts with over $33 \mathrm{~cm} \mathrm{DBH}$, prevailing in the 46 to $62 \mathrm{~cm} \mathrm{DBH}$ classes, close to previous records, despite not reporting fig trees growing in cracks or on top of dead branches (COELHO, 2005).

The hemiepiphytes observed in this study occurred mostly in the tree height class of 14 to 15.99 meters. In addition, over $50 \%$ of the hemiepiphytes were found on bifurcactions (similar to Coelho 2005). However, for Coelho (2005), the occurrence of Ficus on bifurcations was higher, followed by the occurrence on nodes (places from where branches fell). These nodes are comparable to the "hollows of the branches" of this study, which, for the most part, were previously pruned branches that hollowed out at this location.

Coelho (2005) compared individuals of the genus Ficus and Coussapoa and reported a 
higher density of Coussapoa. However, individuals of this genus were not recorded in this study. Ficus individuals reached a larger size, had greater specialization as regards substrate, establishment diameter and fixation of the root to the host with a complex structure, unlike the individuals of Coussapoa (simpler stemming system). The two genera have the same patterns regarding establishment height, places of establishment, plasticity of habits (both genera have been reported on the ground, ruins and tree species) and type of damage caused to the host (both lethal).

\section{Conclusions}

A total of four species of primary hemiepiphytes belonging to the genus Ficus (Moraceae) were recorded. The hemiepiphytes occurred only on adult trees with over eight meters in height, and with DBH between 46 to $62 \mathrm{~cm}$ in diameter.

The hemiepiphytes were observed holding mostly $P$. pluviosa individuals, the most abundant species among the evaluated adults. Hemiepiphytes were recorded holding specimens of Libidibia ferrea, C. speciosa, A. lebbeck and $P$. aquatica. Most of the hemiepiphytes were found in bifurcations, mostly in trunk bifurcations, followed by branch bifurcations.

Since epiphytes are species that have a large production of biomass, their proper management must be done to prevent trees in urban areas from being damaged and, consequently, causing damage to the population. Handling such as total removal, or at least maintenance cleaning. Studies that better guide how to manage epiphytes in relation to each species of interest in urban forestry should be considered for the future.

\section{References}

BORGO, M.; SILVA, S. M. Epífitos vasculares em fragmentos de Floresta Ombrófila Mista,
Curitiba, Paraná, Brasil. Revista Brasileira de Botânica, v. 26, n, 3, p. 391-401, 2003.

BUZATTO, C. R.; SEVERO, B. M. A.; WAECHTER, J. L. Composição florística e distribuição ecológica de epífitos vasculares na Floresta Nacional de Passo Fundo, Rio Grande do Sul. Iheringia, Série Botânica, v. 63, n. 2, p. 231-239, 2008.

CARDOSO, M. R. D.; MARCUZZO, F. F. N.; BARROS, J. R. Classificação climática de Köppen-Geiger para o estado de Goiás e o Distrito Federal. Acta Geográfica, v. 8, n. 16, p. 40-55, 2014.

COBLE, A. P.; FOGEL, M. L.; PARKER, G. G. Canopy gradients in leaf functional traits for species that differ in growth strategies and shade tolerance. Tree physiology, v. 37, n. 10, p. 1415-1425, 2017.

COELHO L. F. M. Ecologia de hemiepífitas estranguladoras no Parque Estadual da Ilha do Cardoso. 2005. 97f. Dissertação (Mestrado em Ciências Biológicas). Universidade Estadual Paulista, Rio Claro, SP.

DEVENS, K. U.; GERALDINI, A. P. B.; AMADEO, R. M.; CAXAMBU, M. G.; MAGNONI, P. H. J. Levantamento de epífitas na arborização urbana do município de Luiziana - PARANÁ. Revista da Sociedade Brasileira de Arborização Urbana, v. 10, n. 4, p. 1-11, 2015.

DISLICH R. Florística e estrutura do componente epifítico vascular na mata da Reserva da Cidade Universitária "Armando Salles de Oliveira", São Paulo, SP. 1996. 183f. Dissertação (Mestrado em Ecologia). Universidade de São Paulo, São Paulo, SP, 1996.

FABRICANTE, J. R.; ANDRADE, L. A.; MARQUES, F. J. Componente epifítico vascular ocorrente em árvores urbanas. Cerne, v. 12, n. 4, p. 399-405, 2006. 
IBGE, INSTITUTO BRASILEIRO DE GEOGRAFIA E ESTATÍSTICA. Goiás: Goiânia. Available in: < http://cidades.ibge.gov.br/xtras/perfil.php?codm un=520870 > . Acess in 20 nov. 2016.

KERSTEN, R. A. Epifitismo vascular na bacia do Alto Iguaçú, Paraná. 2006. 231f. Tese (Doutorado em Engenharia Florestal). Universidade Federal do Paraná, Curitiba, Paraná, 2006.

LUDWIG, F.; MIDDLETON, W.; GALLENMÜLLER, F.; ROGERS, P.; SPECK, T. Living bridges using aerial roots of ficus elastica - an interdisciplinary perspective. Scientific Reports, v. 9, n. 12226, 2019. DOI: https://doi.org/10.1038/s41598-019-48652-w

MANIA, L. F. Florística e distribuição de epífitas vasculares em floresta alta de restinga na planície litorânea da praia da fazenda, Núcleo Picinguaba, Parque Estadual Serra do Mar, município de Ubatuba, SP. 2008. 114f. Dissertação (Mestrado em Ciências Biológicas). Universidade Estadual Paulista, Rio Claro, SP, 2008.

MARCUSSO, G. M.; KAMIMURA, V. A.; MONTEIRO, R. Epiphyte-phorophyte relationships: assessing the differences between Seasonal Semideciduous and Swamp Forests in Southeastern Brazil. Hoehnea, São Paulo, v. 46, n. 2, e232018, 2019. DOI: http://dx.doi.org/10.1590/2236-8906-23/2018.

MATOS, E. C. A.; NASCIMENTO-JUNIOR, J. E.; MARIANO, D. L. S.; OLIVEIRA, A. L. Arborização do bairro centro da cidade de Aracaju, Sergipe, e seus organismos associados. Revista da Sociedade Brasileira de Arborização Urbana, Piracicaba - SP, v.5, n.4, p.22-39, 2010.

OLIVEIRA, R. P. Comunidades epifítica e arbórea em Matas de Galeria no Distrito Federal, Brasil. Brasília, 2013. 101f.
Dissertação (Mestrado em Ciências Florestais). Universidade de Brasília, Brasília, DF, 2013.

PDAU - Plano diretor de arborização urbana de Goiânia. Goiânia: AMMA, 134 p, 2008.

QUARESMA, A. C.; JARDIM, M. A. G. Floristic composition and spatial distribution of vascular epiphytes in the restingas of Maracanã, Brazil. Acta Botanica Brasilica, v. 28, n. 1, p. 68-75, $2014 . \quad$ DOI: https://dx.doi.org/10.1590/S010233062014000100007

RITTER, M. C.; SANTOS, F. R.; CRESPÃO, L. M. P.; ARDENGUI, T. C.; CAXAMBU, M. G. Levantamento de epífitas presentes na arborização urbana no município de Farol Paraná. Revista da Sociedade Brasileira de Arborização Urbana, v. 9, n. 3, p. 18-28, 2014.

SANTOS, A. C. L. Composição florística e estrutura da comunidade de epífitas vasculares associadas a trilhas no Parque Estadual das Fontes do Ipiranga, São Paulo, SP, Brasil. São Paulo, 2008. 72 f. Dissertação (Mestrado em Biodiversidade Vegetal e Meio Ambiente). Instituto de Botânica da Secretaria de Estado do Meio Ambiente, São Paulo, 2008.

SEITZ, R. A. A poda de árvores urbanas: $1^{\circ}$ curso em treinamento sobre poda em espécies arbóreas florestais e de arborização urbana. IPEF: USP, Piracicaba, SP, 2016.

WEIRICH, R. A.; CALIL, F. N.; MONTEIRO, M. M.; GONÇALVES, B. B.; SILVA NETP, C. M.; VENTUROLI, F. Arborização urbana para mitigação das condições microclimáticas em Goiânia, Goiás. Ecologia e Nutrição Florestal, v. 3, n. 2, p. 48-58, 2015. 